\title{
Fuzzy-based Decision for Coronary Heart Disease Diagnosis: Systematic Literature Review
}

\author{
Afrina Safira Dianirani ${ }^{1 *}$, Zefanya Debby Claudia ${ }^{2}$ \\ ${ }^{1,2}$ Computer Science Department, School of Computer Science, \\ Bina Nusantara University, \\ Jakarta, Indonesia 11480 \\ afrina.dianirani@binus.ac.id; zefanya.claudia@binus.ac.id \\ *Correspondence: afrina.dianirani@binus.ac.id
}

\begin{abstract}
A build-up of fatty substance and plaque within the coronary arteries typically causes coronary heart disease. Around the world, the mortality rate caused by coronary heart disease is threatening. The majority of people from developed countries have suffered from heart disease over the last two decades. At early stages, the diagnosis of these illnesses helps patients decrease the risk of mortality and therefore minimize the cost of care. Health diagnostic decisions are often focused on the experiences of specialists. In certain cases, not all the insights of the expert lead to the accurate diagnosis of a disease. For medical diagnosis in the area of healthcare, several experimental approaches have been proposed. However, it remains difficult to determine the functionality of testing devices for coronary heart disorders. The purpose of this paper is to undertake a literature review on fuzzy-based decisionmaking for the diagnosis of coronary heart disease. The study then gathered results pertaining to fuzzy-based decision-making for the diagnosis of coronary heart disease from 2016-2021.
\end{abstract}

Keywords: Coronary Heart Disease; Fuzzy-based System; Medical Diagnosis.

\section{INTRODUCTION}

Competent heart function greatly affects our life, because the heart is an important part of our body. If the heart function does not work properly, it will affect other parts of the human body such as the brain, kidneys etc [18]. Some heart diseases are caused by bad habits that humans do such as watching TV for too long, letting stress, ignoring snoring, drinking alcohol, eating too much, smoking and living with smokers, not consuming fiber, especially fruits and vegetables and so on. Because there are many and less clear risk factors for heart disease, ordinary people will find it difficult to know this disease. The most common death is due to the condition that affects the heart is Cardiovascular disease (CVD). The foremost reason of illness and death that causes by narrowing the blood vessels those supplying oxygen and blood to the heart[15], leads to the symptoms like fatigue and chest pain (angina) [2]. The Heart disease is one of risky disease and need to diagnosis in early time to surmount it's risk[1]. Basically, most heart failure occurs due to coronary problems, high blood pressure, and diabetes which can damage the heart. In 2015, the World Health Organization (WHO) estimated that one-third of all causes of global death were cardiovascular disease and estimated that approximately 17.7 million people lost their lives due to cardiovascular disease. This population represented $31 \%$ of all deaths [4]. Based on WHO estimates in 2030, nearly 23.6 million people suffer from heart disease. So, to minimize this it is necessary to analyze coronary disease. Coronary disease examination is usually in terms of signs, manifestations and physical examination of the patient [17]. For many people the first sign of heart dysfunction is a heart attack that occurs when the blood clot in the coronary arteries blocks the flow of blood into a part of the heart muscle [14].

Diagnosis of heart disease is important, but due to the many uncertainties and risk factors it is sometimes difficult for experts to diagnose heart disease. When a heart attack is identified, the speed of detection is critical to save the lives of those with heart attack and prevent heart damage. Medical diagnosis requires accurate and efficient surgery. To increase the accuracy of diagnosis and reduce the mortality rate of cardiovascular disease, it is necessary to carry out a correct diagnosis at an early stage. There are many factors to analyze heart disease, because it is a difficult job to diagnose a patient. Thus, an accurate and fast tool is 
required that takes these risk factors into account and shows certain results in linguistic terms [5]. For the diagnosis of heart disease, besides conventional methods, there are several decision support systems that use computational techniques, namely artificial neural networks (ANN), fuzzy logic, neuro-fuzzy, machine learning and others.

Now a day the use of computer technology is very important in every field, including the field of medical diagnosis. Diagnostic decisions depend on experience, expertise and use of appropriate methods with strong logical reasoning abilities. for this field, where computers are used which have very high complexity and disorderly. For this reason, expert systems such as fuzzy logic are used, because fuzzy logic is a powerful method of reasoning that can handle data uncertainty very well. [3]. Fuzzy systems are increasingly being used in a wide variety of practical applications in medicine, control, classification, prediction, inference, decision making, image segmentation and medical diagnosis. [16].

Fuzzy logic theory presents a mathematical theory to capture inconsistencies with human cognitive processes, such as thinking and reasoning. The development of fuzzy logic was largely motivated by the need for a conceptual framework that could address the problem of lexical imprecision [13]. Fuzzy logic refers to a group of many valuable logics, used to solve various challenges, one of which is clinical diagnostics. Fuzzy logic is an extension of classical logic which is based on Boolean logic. Variables in fuzzy logic can use accurate values between 0 and 1 in a traditional binary set instead of using true or false. In addition, fuzzy logic provides a method for making informed decisions. In general, fuzzy logic is used for applications in control systems to make decisions more quickly [6]. The researchers proposed a fuzzy soft expert system for the early detection of heart disease based on the fuzzy soft set theory. Their proposed system based on four parts i.e. fuzzy values; fuzzy soft set, fuzzy soft set parameter, and an algorithm. The study based on systolic blood pressure, low-density lipoprotein cholesterol, blood sugar, maximum heart rate, old pack and age variables. It is perceived that the suggested model is supportive for the medical experts in taking decisions regarding heart diseases [11].

Computational intelligence techniques: Fuzzy System, Swarm Intelligence, Evolutionary Computing, and Neural Network are mostly used in different fields of sciences like Intelligent Diagnose System, Smart Health, Smart City, Cloud Computing, Robotics, Wireless communication etc. Nowadays, hybrid structures of these four branches are very popular due to their performance. In last decades predictions of the medical disease using machine learning approaches are one of the hot research areas[9]. Several intelligent systems have been improved aiming to improve health care and offer better health care facilities, reduce costs, and much more. Soft computing has been effectively implemented in bioinformatics so that it offers low cost, low cost estimation, better estimation and of course a good and more precise solution. from the patient data set is used to predict the likelihood of heart attack using data mining strategies, fuzzy logic and find out which model provides the most correct predictions for diagnosis [10].

This proposed methodology depended on Decision Tree and Naïve Bayes. The six parameters were diminished into four parameters i.e. Chest pain, blood pressure, No. of vessels colored and treadmill test which had less expense of lab test. In the proposed system, the output based on Normal, Low Risk, Medium Risk, and High Risk. The results stored in the database that connected with this model. In the database, the patient's record was maintained. The correctness and efficiency were measured through Naïve Bayes and Decision Tree using fuzzy logic[9]. With the help of machine learning and data mining techniques such as $\mathrm{KNN}$ and genetic algorithms, disease will be predicted more effectively and accurately. Fuzzy expert systems use membership functions, fuzzy input, output variables and fuzzy rule bases. Fuzzy expert system to predict coronary disease by utilizing data mining algorithms. This strategy would be most appropriate for predicting coronary disease using machine learning [12].

\section{METHODS}

This paper is based on a systematic literature review. A systematic literature review identifies, selects, and objectively evaluates studies in order to address a clearly stated question. For a systematic assessment, a well-defined protocol or technique should be used, with the conditions explicitly stated before the analysis begins. It's a simple, systematic search that can be continued and replicated by other researchers through a variety of databases and grey literature. It reviews what has been done in the context of a subject. The author uses 20 publications in this paper to diagnose coronary heart disease using a keyword-based search mechanism related to fuzzy decision-making. Coronary Heart Disease, Fuzzy-based System, and Medical Diagnosis are some of the keywords that were used. The paper used was found on Google Scholar, and it was published between 2016 and 2021 .

\section{RESULTS AND DISCUSSION}

RQ1: What are data needed for a fuzzy-based decision for coronary heart disease diagnosis?

From twenty studies, there are fifteen data needed for a fuzzy-based decision for coronary heart diagnosis.

Table 1: Data needed for a fuzzy-based decision for coronary heart diagnosis

\begin{tabular}{cccc}
\hline No & Data Needed & $\begin{array}{c}\text { Literature } \\
\text { Citations }\end{array}$ & Number \\
\hline & & {$[1][2][3][4][5][6]$} & \\
1 & Age & {$[7][9][11][12][13]$} & 16 \\
& & {$[14][15][16][17]$} & \\
& & {$[20]$} & \\
\hline \multirow{2}{*}{2} & Sex & {$[1][2][3][4][7][12]$} & \multirow{2}{*}{10} \\
& & {$[13][15][16][17]$} & \\
\hline
\end{tabular}




\begin{tabular}{|c|c|c|c|}
\hline 3 & Chest Pain & $\begin{array}{l}{[1][2][3][4][5][7]} \\
[8][9][13] 16][17]\end{array}$ & 11 \\
\hline 4 & Blood Pressure & $\begin{array}{c}{[1][2][4][6][7][8]} \\
{[9][11][13][14][15]} \\
{[16][17]}\end{array}$ & 13 \\
\hline 5 & Cholesterol & $\begin{array}{c}{[1][2][3][4][5][6]} \\
{[7][8][9][11][12]} \\
{[13][14][15][16]} \\
{[17]}\end{array}$ & 16 \\
\hline 6 & Blood Sugar & $\begin{array}{c}{[1][2][3][4][5][6]} \\
{[7][8][9][12][13]} \\
{[15][16][17]}\end{array}$ & 14 \\
\hline 7 & Thallium Scan & $\begin{array}{c}{[1][2][3][7][13]} \\
{[16][17][20]}\end{array}$ & 8 \\
\hline 8 & Old Peak & $\begin{array}{c}{[1][3][4][7][11]} \\
{[13][14][16][17]}\end{array}$ & 9 \\
\hline 9 & Electrocardiography & $\begin{array}{c}{[1][2][3][4][5][7]} \\
{[9][13][16][17]}\end{array}$ & 10 \\
\hline 10 & $\begin{array}{l}\text { Maximum Heart } \\
\text { Rate }\end{array}$ & $\begin{array}{c}{[1][2][3][4][5][7]} \\
{[8][11][12][13][16]} \\
{[17]}\end{array}$ & 12 \\
\hline 11 & Obesity & {$[12][15]$} & 2 \\
\hline 12 & $\begin{array}{c}\text { Exercise Induced } \\
\text { Angina }\end{array}$ & $\begin{array}{c}{[1][2][4][7][13]} \\
{[16][17]}\end{array}$ & 7 \\
\hline 13 & $\begin{array}{c}\text { Number of Major } \\
\text { Vessels }\end{array}$ & {$[2][4][7][16][17]$} & 5 \\
\hline 14 & $\begin{array}{l}\text { Slope of Peak } \\
\text { Exercise }\end{array}$ & {$[2][4][7][16][17]$} & 5 \\
\hline 15 & $\begin{array}{l}\text { Family History of } \\
\text { Early Heart Disease }\end{array}$ & {$[12][15]$} & 2 \\
\hline
\end{tabular}

RQ2: What steps to use for a fuzzy-based decision for coronary heart disease diagnosis?

From twenty studies, there are many steps for a fuzzy-based decision for coronary heart diagnosis.

Table 2: Steps to use for a fuzzy-based decision for coronary heart diagnosis

\begin{tabular}{|c|c|c|c|}
\hline Author & Year & Steps & $\begin{array}{l}\text { Number } \\
\text { of Steps }\end{array}$ \\
\hline $\begin{array}{c}\text { Hussin Attya } \\
\text { Lafta \& Wed } \\
\text { Kadhim Oleiwi }\end{array}$ & 2017 & $\begin{array}{l}\text { Fuzzification } \\
\text { Defuzzification } \\
\text { Fuzzy Petri Net }\end{array}$ & 3 \\
\hline $\begin{array}{l}\text { P. Umasankar \& } \\
\text { V. Thiagarasu }\end{array}$ & 2018 & $\begin{array}{c}\text { Pre-Processing Step } \\
\text { Interval Vague Set } \\
\text { Fuzzy Association } \\
\text { Rule Mining } \\
\text { Fuzzy Correlation } \\
\text { Rule Mining }\end{array}$ & 4 \\
\hline $\begin{array}{l}\text { Tanmay Kasbe \& } \\
\text { Ravi Singh Pippal }\end{array}$ & 2017 & $\begin{array}{c}\text { Fuzzy Membership } \\
\text { Function } \\
\text { Fuzzy Expert } \\
\text { System Design } \\
\text { Fuzzy Data Rule } \\
\text { Base }\end{array}$ & 3 \\
\hline
\end{tabular}

\begin{tabular}{|c|c|c|c|}
\hline $\begin{array}{c}\text { Kaan Uyara \& } \\
\text { Ahmet İlhan }\end{array}$ & 2017 & $\begin{array}{l}\text { GA based trained } \\
\text { RFNN } \\
\text { Evaluation criteria }\end{array}$ & 2 \\
\hline $\begin{array}{c}\text { Ali Mohammad } \\
\text { Alqudah }\end{array}$ & 2017 & $\begin{array}{l}\text { System algorithm } \\
\text { Membership } \\
\text { function, inputs, } \\
\text { and output }\end{array}$ & 2 \\
\hline $\begin{array}{l}\text { Hasan Kahtan, } \\
\text { Kamal Z. } \\
\text { Zamli, Wan Nor } \\
\text { Ashikin Wan } \\
\text { Ahmad Fatthi, } \\
\text { Azma Abdullah, } \\
\text { Mansoor } \\
\text { Abdulleteef, } \\
\text { \& Noor } \\
\text { Shahaiyusniezam } \\
\text { Kamarulzaman }\end{array}$ & 2018 & $\begin{array}{c}\text { Fuzzification } \\
\text { Fuzzy Rule Base } \\
\text { Fuzzy Inference } \\
\text { Engine } \\
\text { Defuzzification } \\
\text { Application using } \\
\text { Java }\end{array}$ & 5 \\
\hline $\begin{array}{l}\text { G. Thippa } \\
\text { Reddy, M. } \\
\text { Praveen Kumar } \\
\text { Reddy, Kuruva } \\
\text { Lakshmanna, } \\
\text { Dharmendra } \\
\text { Singh Rajput, } \\
\text { Rajesh Kaluri1, } \\
\text { \& Gautam } \\
\text { Srivastava }\end{array}$ & 2019 & $\begin{array}{c}\text { Normalization } \\
\text { Attribute Reduction } \\
\text { using Rough Sets } \\
\text { Solution } \\
\text { Representation } \\
\text { Fitness Function } \\
\text { Termination } \\
\text { Criteria } \\
\text { Prediction Based } \\
\text { on Fuzzy Logic } \\
\text { System }\end{array}$ & 6 \\
\hline $\begin{array}{c}\text { Peyman Rezaei } \\
\text { Hachesu, Mahsa } \\
\text { Dehghani Soufi, } \\
\text { Ruhollah Khara, } \\
\text { Nazila Moftian, } \\
\text { \& Taha Samad } \\
\text { Soltan }\end{array}$ & 2019 & $\begin{array}{l}\text { Fuzzification } \\
\text { Knowledge base } \\
\text { Decision logic } \\
\text { Defuzzification }\end{array}$ & 4 \\
\hline $\begin{array}{l}\text { Iftikhar Naseer, } \\
\text { Bilal Shoaib } \\
\text { Khan, Shazia } \\
\text { Saqib, Syed } \\
\text { Nadeem Tahir, } \\
\text { Sheraz Tariq, } \\
\text { \& Muhammad } \\
\text { Saleem Akhter }\end{array}$ & 2019 & $\begin{array}{l}\text { Proposed DHD- } \\
\text { MFI Expert System } \\
\text { Input Fuzzy Sets } \\
\text { Output Fuzzy Sets } \\
\text { Membership } \\
\text { Functions } \\
\text { Graphical } \\
\text { Representation } \\
\text { of Membership } \\
\text { Function } \\
\text { Fuzzy Proposition } \\
\text { Rule Base } \\
\text { Fuzzy Inference } \\
\text { Engine } \\
\text { Product Inference } \\
\text { Engine } \\
\text { De-fuzzifier }\end{array}$ & 10 \\
\hline
\end{tabular}




\begin{tabular}{|c|c|c|c|}
\hline $\begin{array}{l}\text { G. Thippa Reddy } \\
\text { \& Neelu Khare }\end{array}$ & 2017 & $\begin{array}{c}\text { Discretization } \\
\text { Solution encoding } \\
\text { Oppositional } \\
\text { solution generation } \\
\text { Fitness evaluation } \\
\text { Novel hybrid } \\
\text { OFBAT algorithm } \\
\text { Fuzzy system } \\
\text { Design of fuzzy } \\
\text { system } \\
\text { Rule-based fuzzy } \\
\text { score computation }\end{array}$ & 8 \\
\hline $\begin{array}{c}\text { Nasruddin } \\
\text { Hassan, Osama } \\
\text { Rashed Sayed, } \\
\text { Ahmed Mostafa } \\
\text { Khalil, \& } \\
\text { Mohamed Abdel } \\
\text { Ghany }\end{array}$ & 2016 & $\begin{array}{l}\text { Input and output } \\
\text { variables } \\
\text { Fuzzy membership } \\
\text { functions for each } \\
\text { variable } \\
\text { Fuzzy rules. }\end{array}$ & 3 \\
\hline Ion Iancu & 2017 & $\begin{array}{c}\text { Input and output } \\
\text { variables } \\
\text { Fuzzy rule base } \\
\text { Fuzzification and } \\
\text { firing level } \\
\text { Inferred conclusion } \\
\text { Defuzzification and } \\
\text { output result }\end{array}$ & 5 \\
\hline $\begin{array}{l}\text { S. Moameria \& } \\
\text { N. Samadinai }\end{array}$ & 2018 & $\begin{array}{l}\text { UCI Heart Data Set } \\
\text { Preprocessing } \\
\text { Decision Tree } \\
\text { The Fuzzy } \\
\text { Inference System } \\
\text { Cuckoo Search } \\
\text { Optimization of } \\
\text { Fuzzy Membership } \\
\text { Values }\end{array}$ & 5 \\
\hline Farnaz Sabahi & 2018 & $\begin{array}{c}\text { Structuring decision } \\
\text { hierarchy } \\
\text { Combining soft } \\
\text { data and statistical } \\
\text { data } \\
\text { Computing fuzzy } \\
\text { validity } \\
\text { Developing } \\
\text { pairwise matrices } \\
\text { with inclusion of } \\
\text { validity } \\
\text { Deriving Priorities } \\
\text { Aggregation of } \\
\text { Priorities } \\
\text { Ranking }\end{array}$ & 7 \\
\hline $\begin{array}{l}\text { Animesh Kumar } \\
\text { Paul, Pintu } \\
\text { Chandra Shill, } \\
\text { Md. Rafiqul } \\
\text { Islam Rabin, \& } \\
\text { Kazuyuki Murase }\end{array}$ & 2017 & $\begin{array}{c}\text { Encoding the fuzzy } \\
\text { rules } \\
\text { Objective function } \\
\text { Weighting the } \\
\text { generated fuzzy } \\
\text { rules } \\
\text { Fuzzy DSS } \\
\text { effectiveness }\end{array}$ & 4 \\
\hline
\end{tabular}

\begin{tabular}{|c|c|c|c|}
\hline $\begin{array}{c}\text { Purushottam } \\
\text { Sharma \& Kanak } \\
\text { Saxena }\end{array}$ & 2017 & $\begin{array}{l}\text { Instigation of a } \\
\text { decision tree from } \\
\text { the data } \\
\text { Generation of a } \\
\text { set of rules from } \\
\text { the decision tree, } \\
\text { using disjunctive } \\
\text { ordinary structure } \\
\text { and detailing of a } \\
\text { crisp model } \\
\text { Fuzzy model } \\
\text { generation using } \\
\text { ruleset } \\
\text { Enhancing the } \\
\text { fuzzy model } \\
\text { parameter: the } \\
\text { framework was } \\
\text { consequently } \\
\text { produced from } \\
\text { an introductory } \\
\text { explained set of } \\
\text { data }\end{array}$ & 4 \\
\hline $\begin{array}{l}\text { V. Krishnaiah, G. } \\
\text { Narsimha, PhD, } \\
\& \text { N. Subhash } \\
\text { Chandra, PhD }\end{array}$ & 2016 & $\begin{array}{l}\text { Classification } \\
\text { Clustering } \\
\text { Association } \\
\text { Prediction }\end{array}$ & 4 \\
\hline $\begin{array}{c}\text { Mehrbakhsh } \\
\text { Nilashi, Hossein } \\
\text { Ahmadi, Azizah } \\
\text { Abdul Manaf, } \\
\text { Tarik A. Rashid, } \\
\text { Sarminah Samad, } \\
\text { Leila Shahmoradi, } \\
\text { Nahla Aljojo, \& } \\
\text { Elnaz Akbari }\end{array}$ & 2020 & $\begin{array}{c}\text { Data pre-processing } \\
\text { Clustering } \\
\text { Dimensionality } \\
\text { Reduction } \\
\text { Classification }\end{array}$ & 4 \\
\hline $\begin{array}{l}\text { Animesh Kumar } \\
\text { Paul, Pintu } \\
\text { Chandra Shill, } \\
\text { Md. Rafiqul Islam } \\
\text { Rabin, \& M. A. } \\
\text { H. Akhand }\end{array}$ & 2016 & $\begin{array}{l}\text { Encoding the Fuzzy } \\
\text { Rules } \\
\text { Objective function } \\
\text { Weighting the } \\
\text { generated Fuzzy } \\
\text { Rules } \\
\text { Fuzzy System } \\
\text { Effectiveness }\end{array}$ & 4 \\
\hline
\end{tabular}

\section{CONCLUSION}

In this study, a fuzzy rule-based system can be used for the diagnosis of coronary heart disease considering its accuracy and transparency. The resulting fuzzy rules can be easily understood by doctors because they use natural linguistic terms that describe the relationship between the factors and the results of the diagnosis. This study proposes a heart disease diagnosis system that uses fuzzy logic in order to assist patients in taking preventive measures.

In addition, the use of fuzzy logic can provide a competent means of assisting inexperienced physicians in diagnosing heart disease quickly and adeptly. with that if there is the possibility of complications can be diagnosed properly. This system will be able to diagnose coronary artery heart disease by including various risk factors such as hypertension, age, gender, smoking, family history and so on. 
Several analyzes show that different technologies are used, and the number of samples used in each study is different, so that when you want to know to achieve accuracy results will also be different, it depends on the tools used for implementation.

The fuzzy logic method is considered to be able to develop a heart disease diagnosis system because the fuzzy logic method has the ability to operate in approximate reasoning and find accurate solutions. Fuzzy expert systems integrate fuzzy logic elements, which are a logically consistent way of reasoning that can address the uncertainty, ambiguity and imprecision inherent in medical diagnosis.

\section{REFERENCES}

[1] Laftah, Hussin Attya; Oleiwi, Wed Kadhim. (2017). A Fuzzy Petri Nets System for Heart Disease Diagnosis. Journal of Babylon University, Pure and Applied Sciences, 25.

${ }^{[2]}$ Kasbe, T; Pippal, R. S. (2017). Design of Heart Disease Diagnosis System using Fuzzy Logic. International Conference on Energy, Communication, Data Analytics and Soft Computing (ICECDS-2017), 3183-3187.

${ }^{[3]}$ Kahtan, H; Zamli, K. Z; Fatthi, W. N; Abdullah, A; Abdulleteef, Mr; Kamarulzaman, N. S. (2018). Heart Disease Diagnosis System Using Fuzzy Logic. ICSCA 2018: Proceedings of the 2018 th International Conference on Software and Computer Applications,

[4] Umasankar, P; Thiagarasu, V. (2018). Decision Support System for Heart Disease Diagnosis Using Interval Vague Set and Fuzzy Association Rule Mining. Fourth International Conference on Devices, Circuits and Systems (ICDCS'18), 223-227.

${ }^{[5]}$ Uyar, Kaan; İlhan, Ahmet. (2017). Diagnosis of heart disease using genetic algorithm based trained recurrent fuzzy neural networks. Procedia Computer Science, 120, 588-593.

${ }^{[6]}$ Reddy, G. T; Reddy, M. P. K; Lakshmanna, K; Rajput, D. S; Kaluri, R; Srivastava, G. (2019). Hybrid genetic algorithm and a fuzzy logic classifier for heart disease diagnosis. Evolutionary Intelligence.

[7] Alqudah, Ali Mohammad (2017). Fuzzy expert system for coronary heart disease diagnosis in Jordan. Health and Technology, 7(2-3), 215-222.

${ }^{[8]}$ Hachesu, P. R; Soufi, M. D; Khara, R; Moftian, N; Soltani, S. T. (2019). A fuzzy mobile decision support system for diagnosing of the angiographic status of heart disease. IEngineering and Applied Science Research.

${ }^{[9]}$ Naseer, Iftikhar; Khan, Bilal Shoaib; Saqib, Shazia; Tahir, Syed Nadeem; Tariq, Sheraz; Akhter, Muhammad Saleem. (2020). Diagnosis Heart Disease Using Mamdani Fuzzy Inference Expert System.
EAI Endorsed Transactions on Scalable Information Systems, 7(26).

${ }^{[10]}$ Reddy, G. T; Khare, N. (2017). An Efficient System for Heart Disease Prediction Using Hybrid OFBAT with Rule-Based Fuzzy Logic Model. Journal of Circuits, Systems and Computers, 26(04), 1750061 .

[11] Hassan, Nasruddin; Sayed, Osama Rashed; Khalil, Ahmed Mostafa; Ghany, Mohamed Abdel. (2016). Fuzzy Soft Expert System in Prediction of Coronary Artery Disease. International Journal of Fuzzy Systems, 19(5), 1546-1559.

[12] Jain, Prerna; Kaur, Amandeep. (2019). A Fuzzy Expert System for Coronary Artery Disease Diagnosis. ICAICR '19: Proceedings of the Third International Conference on Advanced Informatics for Computing Research, 47, 1-6.

${ }^{[13]}$ Iancu, I. (2018). Heart disease diagnosis based on mediative fuzzy logic. Artificial Intelligence in Medicine, 89, 51-60.

[14] Maomeri, S; Samadinai, N. (2018). Diagnosis of Coronary Artery Disease via a Novel Fuzzy Expert System Optimized by Cuckoo Search. IJE TRANSACTIONS, Vol. 31, No. 12, 2028-2036.

${ }^{[15]}$ Sabahi, F. (2018). Bimodal fuzzy analytic hierarchy process (BFAHP) for coronary heart disease risk assessment. Journal of Biomedical Informatics, 83, 204-216.

[16] Paul, A. K; Shill, P. C; Rabin, M. R. I; Murase, K. (2017). Adaptive weighted fuzzy rule-based system for the risk level assessment of heart disease. $A p$ plied Intelligence, 48(7), 1739-1756.

[17] Sharma, P., \& Saxena, K. (2017). Application of fuzzy logic and genetic algorithm in heart disease risk level prediction. International Journal of System Assurance Engineering and Management, 8(S2), 1109-1125.

${ }^{[18]}$ Krishnaiah, V; Narsimha, G; Chandra, N. S. (2016). Heart Disease Prediction System using Data Mining Techniques and Intelligent Fuzzy Approach: A Review. International Journal of Computer Applications (0975 - 8887) Volume 136-No.2.

[19] Nilashi, M; Ahmadi, H; Manaf, A. A; Rashid, T. A; Samad, S; Shahmoradi, L; Aljojo, N; Akbari, E. (2020). Coronary Heart Disease Diagnosis Through Self-Organizing Map and Fuzzy Support Vector Machine with Incremental Updates. International Journal of Fuzzy Systems.

${ }^{[20]}$ Paul, A. K; Shill, P. C; Rabin, M. R. I; Akhand, M. A. H. (2016). Genetic algorithm based fuzzy decision support system for the diagnosis of heart disease. 2016 5th International Conference on Informatics, Electronics and Vision (ICIEV). 